Article Type: Research Paper

\title{
The Impact of Working Mothers' Bargaining Power on Their Children's Human Capital in Indonesia
}

\author{
Ni Komang Widya Anggaraini ${ }^{1 *}$ and Ni Putu Wiwin Setyari ${ }^{2}$
}

\section{0peN}

\section{AFFILIATION:}

1,2 Department of Economics, Faculty of Economics and Business, Udayana University, Bali, Indonesia.

\section{*CORRESPONDENCE:}

widyaanggaraini@gmail.com

THIS ARTICLE IS AVALILABLE IN:

http://journal.umy.ac.id/index.php/esp

DOI: 10.18196/jesp.21.2.5044

\section{CITATION:}

Anggaraini, N. K. W., \& Setyari, N. P. W. (2020). The Impact of Working Mothers' Bargaining Power on Their Children's Human Capital in Indonesia. Jurnal Ekonomi \& Studi Pembangunan, 21(2), 235-248.

\section{ARTICLE HISTORY}

\section{Received:}

07 Aug 2020

Reviewed:

26 Aug 2020

Revised:

05 Sep 2020

Accepted:

07 Oct 2020
Abstract: Education is one of the strongest instruments owned by society to reduce poverty and vulnerability. This is because knowledge and skills are acquired through education. Thus, increasing productivity and creating access to employment opportunities. So that income will increase along with the increase in education. The most strategic target in developing quality human resources is children. There is an empirical study of the effect on household resource allocation where household decisions are influenced by the power that individuals have in the household. The distribution of power within the household can affect the level of spending on education for each child. This study aims to determine the impact of working mothers on their children's human capital in Indonesia and the differences in the influence of relative education and the relative income of working mother on children's human capital in Indonesia. The analysis technique used is the Ordinary Least Square (OLS) and Chow-test to determine the difference in the effect of the relative education and relative income of working mothers on their children's human capital in Indonesia. Using IFLS5 data, we found out that the impact of working mothers has a significant effect on children's human capital in Indonesia and there is a significant difference where the income of working mothers has a greater influence on children's human capital in Indonesia.

Keywords: Impact; Working Power of Women; Children's Human Capital; OLS; Chow-test

JEL Classification: P46; J24; 015; D31

\section{Introduction}

Development refers to activities carried out by a country or region that aims to develop its people's life quality (Rustiadi, Saefulhakim, \& Panuju 2011). There are several parameters to measure the success of an area's development, one of which is the Human Development Index (HDI) (Maulana \& Bowo, 2013). HDI is a measure to see the impact of regional development performance, which has a very broad dimension because it shows the population quality of an area in terms of life expectancy, education, and a decent standard of living (Melliana \& Zain, 2013). The overall welfare level can be seen from the HDI as a measuring tool because it can describe economic and non-economic factors (Aji, Syarifudin, \& Ishak, 2014). 


\author{
Anggaraini \& Setyari \\ The Impact of Working Mothers' Bargaining Power on Their Children's Human Capital ...
}

From United Nations Development Program (UNDP)'s perspective (2018), human development is formulated to enlarge people's choices and the level achieved from these efforts. The UNDP concept of human development contains four elements: productivity, equity, sustainability, and empowerment. UNDP data (2018) revealed that Indonesia's progress in each HDI indicator put Indonesia in the high human development category, and Indonesia was in 111th position out of 189 countries and regions. The increase of the Indonesian human development index is a positive signal for Indonesia's human resources development.

The increase of human resources can be said as a non-physical investment or better known as human resource investment. It is the number of funds spent and the opportunity to earn income during the investment process. Such investment is called human capital (Simanjuntak, 1985). Thirty years ago, the term human capital was known when Gary S. Becker, a Nobel laureate in economics, wrote a book entitled Human Capital in 1964. The human capital theory proposed by Becker (1975: 17) explains that a person can increase his income by improving education. Income increases with age, where the increase is also directly proportional to individual expertise due to increased education (Nathan, 1989). It can be interpreted that the knowledge and skills possessed will increase to enhance one's productivity. It is the basis for human capital assumptions. Besides, the most strategic target in developing quality human resources is children. Children as part of family members and the next generation are essential to increase human resources in national development. It can be achieved through education. Weiss, Shanteau, and Harries (2006) and Todaro and Smith (2011) stated that education is one of the most powerful instruments a society has, to reduce poverty and vulnerability.

Meanwhile, the issue of gender emerged as a deconstruction of the patriarchal culture that had hegemonized society's paradigm for at least three thousand years. Gender is more emphasized on the differences in roles and functions that exist and is made by society. Gender differences often lead to various inequalities and injustices for women. These forms of gender injustice are not by human rights, so in 1993, the United Nations made a Declaration on the Elimination of Violence Against Women. In Indonesia, the government has worked towards realizing gender equality through Presidential Instruction No. 9 of 2000 concerning Gender Equality in National Development. Besides, the World Bank in the book Engendering Development asserted that gender equality is a major development issue that will strengthen the country's ability to develop, reduce poverty, and run government effectively (Sofiani, 2009). In fact, the times' progress is often accompanied by information development and the level of human intellectual ability, so women's role in life continues to change to respond to the challenges of the times and improve household welfare. According to Mangkuprawira and Vitalaya (2007), women's decisions to work are not only motivated by economic factors but also due to knowledge skills and self-actualization and the desire to gain inner satisfaction. It is caused by the general assumption that the world of work is a world of men so that women will feel that they can sit equal with men by self-actualizing themselves through work; however, women cannot be separated from their nature. Women have the opportunity to appear in a world, which is traditionally considered the world of men because of women's movements and studies (Saskara, 2018). 


\author{
Anggaraini \& Setyari \\ The Impact of Working Mothers' Bargaining Power on Their Children's Human Capital ...
}

The rise of working homemakers creates the formation of a new role for women that is different from normal gender roles, which becomes a critical study. According to Suroto (1992: 15), household welfare can be achieved through additional income obtained by household members, both wife and husband, outside the household life. Once working mothers carry out household activities and public sector activities, they will face conditions where their household economic role becomes increasingly important. At the same time, women get higher formal education opportunities, which enable them to enter competitive employment. It is difficult to identify a causal relationship between maternal educational attainment and children's outcomes because mothers who have higher education levels or return to school tend to be different from mothers who do not (Brooks-Gunn, Guo, \& Furstenberg, 1993; Felmlee, 1988; Leadbeater, 1996; Way \& Leadbeater, 1999). Further, the change in women's role initially led to allegations of changes in household relationship patterns. Changes in women's household roles occur once they work and generate income, creating changes in the men's roles (Nurhamida, 2013). Working mothers have more power in decision-making related to important household decisions, where men whose wives work will be more involved in carrying out household tasks, which tend to be more egalitarian. The power that men (fathers) and women (mothers) have in the household can have different impacts on children's welfare.

This study aims to determine the impact of working mother's bargaining power. Bargaining power in this study was proxied by women's household decision making power over their spouses. It was shown by the relative education and relative income of working mother to children's human capital in Indonesia, where children's human capitals were seen from children's education, namely from the years of schooling. Several empirical studies in the framework of intrahousehold resource allocation that have been conducted in Indonesia have focused on education as an indicator of welfare. There are various other indicators in measuring children's human capital related to education. The residence location, namely the demographics of the area in a village or a city, is very different, where generally children who live in cities have a better quality of human capital than those who live in villages due to advances in technology and information. Apart from access, in this case, the distance from the residence to the school and vice versa from the school to the residence also affects children's education, where the farther the access from home to school, the lower the child's human capital. Also, the mother's and father's age and the number of family members will affect the consumption patterns and household income, including the child's education, where the more the number of individuals in the family, the more the spending.

The imbalance of resource allocation among children is a firm conclusion in several studies that specifically discuss the effects of birth order on intrahousehold resource allocation. The effect of birth order on resource allocation is ambiguous. The theory (biology, psychology, and culture) suggests a negative effect of birth order with resource allocation, indicating that the eldest child will benefit more than younger siblings (Ejrnaes \& Pörtner, 2004). Meanwhile, empirically, the relative order obtained has a positive impact, meaning that children born later get a better resource allocation than their siblings born earlier (Ejrnaes \& Pörtner, 2004; Horton 1988). Therefore, indicators are used as control variables in seeing how women's power affects children's human capital. 


\author{
Anggaraini \& Setyari \\ The Impact of Working Mothers' Bargaining Power on Their Children's Human Capital ...
}

Many studies have included measures that would be considered indicators of women's power, such as ownership of assets (Beegle, Frankenberg, \& Thomas, 2001; Quisumbing \& Maluccio, 1994; Doss 2006; Friedemann-Sa'nchez, 2006; Setyari, Widanta, \& Purbadharmaja, 2018), which provide empirical evidence of the influence on resource allocation household. However, this framework has not been explored much to see the impact of resource allocation within the household on household decisions, especially on working women's bargaining power regarding decisions about their children's education level. In this regard, the combination of short-term and long-term assistance is the government's strategy to sustainably lift the recipients of Program Keluarga Harapan (Conditional Cash Transfer, PKH) out of poverty (Nazara \& Rahayu, 2013). The government has also issued several programs, namely Bantuan Langsung Tunai (Unconditional Cash Transfer, BLT) and Bantuan Langsung Sementara Masyarakat (another type of unconditional cash transfer, BLSM). These programs, especially regarding education, will impact improving the quality of children's human capital, where households that have children and receive the programs can send their children to a higher level of education. In this study, indicators, including residence location, access to education, PKH provided by the government, assets, mother's age, father's age, number of family members, and childbirth order, were used as control variables.

Moreover, the level of children's welfare cannot be separated from the mother's role. Because by using her abilities, a mother can allocate resources owned by the household. It depends on the mother's amount of power in the household to carry out her preferences (Doss, 2013). Therefore, the measure of power is crucial to do, especially mothers, to allocate resources in the household, which will impact their children's welfare. Given that women's role today and in the past is very different, where the progress of the era is often accompanied by the development of information and the level of human intellectual ability, women's role in life continues to change to respond to the challenges of the times and improve household welfare. When women who work not only carry out household activities but have already carried out activities in the public sector, they will face conditions where their roles will be increasingly complex. As well, children who are the younger generation are expected to become the nation's successor and the ideals of national development. In connection with these two things, working mothers who have power in household decision-making will impact children's human capital in Indonesia.

\title{
Research Method
}

This research was conducted in Indonesia because it used IFLS Micro Data. In this case, the Indonesia Family Life Survey (IFLS) or Survey of the Aspects of Indonesian Household Life (SAKERTI) is the most comprehensive longitudinal household survey ever conducted in Indonesia. It is carried out and collected by an organization or institution called RAND. The IFLS data employed in this research was IFLS5, which was passed down between late October 2014 and late April 2015 with remote tracking until the end of August 2015, adding the following modules beyond those used in IFLS4. This paper utilized IFLS-5 data, 
with criteria from respondents: households where working mothers had school children aged 6-18 and had a life partner.

Data analysis methods used in this study were Ordinary Least Square (OLS) and Chowtest. The impact of the working mother's power $(X)$ on children's human capital in Indonesia $(\mathrm{Y})$ could be formulated by the following equation:

$\widehat{Y}_{i}=\beta_{0}+\beta_{1} \Theta_{i}+\beta_{k} X_{k i}$

Information:

$\widehat{\mathrm{Y}}_{1} \quad=$ Children's human capital

$\beta_{0} . \beta_{1} \cdot \beta_{k}=$ Regression coefficient of each $\Theta_{1}, X_{k}$

$\theta \quad=$ The relative power of working mother as measured by the relative education and relative income of working mother against her partner

$\mathrm{X}_{\mathrm{k}}=$ Control Variable $\left(\mathrm{X}_{3}, \mathrm{X}_{4}, \mathrm{X}_{5}, \mathrm{X}_{6}, \mathrm{X}_{7}, \mathrm{X}_{8}, \mathrm{X}_{9}, \mathrm{X}_{10}, \mathrm{X}_{11}, \mathrm{X}_{12}, \mathrm{X}_{13}, \mathrm{X}_{14}, \mathrm{X}_{15}\right)$

However, at the time of testing, there would be two models, namely:

$\widehat{Y}_{i}=\beta_{0}+\beta 1_{1} X 1_{1 i}+\beta_{k} X_{k i}$

Information:

$\mathrm{X} 1_{1} \quad=$ the relative education of the working mother

$\widehat{Y}_{i} \quad=\beta_{0}+\beta 1_{1} X 1_{2 i}+\beta_{k} X_{k i}$.

Information:

$\mathrm{X}_{2} \quad=$ relative income of the working mother

The test to determine the difference in the effect between relative education and working mothers' relative income on children's human capital in Indonesia employed the Chowtest. Chow-test is a tool to test the equality of coefficients or the coefficient similarity test, and this test was found by Gregory Chow. The Chow test can be used to detect whether there are differences between groups (Wooldridge, 2016). The standard F-test could be used for this purpose in an unlimited model that included the interaction between the dummy and all variables. If the value of $F$ count $>F$ table or if sig $F<0.1$, then the null hypothesis is rejected and concludes that there is a different influence between the power of working mother as proxied by working mother's relative education and relative income on children's human capital in Indonesia.

\section{Result and Discussion}

Several studies that have focused on the distribution of power in households to children's education include Klugman, Hanmer, Twigg, Hasan, McCleary-Sills, and Santamaria (2012) and Wong (2012), where the distribution of power in household decision-making, especially for women, has been shown to improve welfare by increasing human capital in the household. From the IFLS wave, four data used in this study consisted of variables of 
relative income, relative education, location, $\mathrm{PKH}$, age of working mother, age of spouse, age of children, number of family members, birth order, and child status. However, by making the test more restricted/increasing the variables, namely the variables of assets and access, there was a decrease in the number of observations. In this study, 2,301 people were categorized as children, and the working mother's average age was 37 years old.

Table 1 is a summary of the descriptive statistics of all variables used in this study. Educ_ar2014 is children's human capital in Indonesia, namely children's education, measured by the number of years they have studied. This variable was used as an outcome variable. Meanwhile, relative_educ and relative_income are the projected impact of working mothers' power with relative education and relative income against their partners and include several indicators used to control the impact of women's power at work on children's human capital in Indonesia.

Table 1 Descriptive statistics

\begin{tabular}{|c|c|c|c|c|c|}
\hline Variable & Obs & Mean & std. dev. & Min & Max \\
\hline Human Capital & 2.355 & 3.677707 & 2.475743 & 0 & 11 \\
\hline Relative_Educ & 2.355 & 1.220171 & 1.090919 & .0833333 & 12 \\
\hline Relative_Income & 2.355 & 21.49927 & 25.9138 & 0 & 100 \\
\hline Location & 2.355 & .5027601 & .5000986 & 0 & 1 \\
\hline \multicolumn{6}{|c|}{ The dummy variable ( 1 for urban, 0 for others) } \\
\hline BLSM & 2.355 & .1626327 & .3691086 & 0 & 1 \\
\hline \multicolumn{6}{|c|}{ The dummy variable ( 1 for BLSM recipient, 0 for others) } \\
\hline PKH & 2.355 & .0454352 & .208301 & 0 & 1 \\
\hline \multicolumn{6}{|c|}{ The dummy variable (1 for PKH recipients, 0 others) } \\
\hline BLT & 2.355 & .1757962 & .3807275 & 0 & 1 \\
\hline \multicolumn{6}{|c|}{ The dummy variable ( 1 for BLT recipients, 0 for others) } \\
\hline Women's Age & 2.355 & 37.2259 & 6.529126 & 21 & 67 \\
\hline Partner's Age & 2.355 & 41.7617 & 7.440428 & 24 & 79 \\
\hline Children's Age & 2.355 & 10.06879 & 2.467706 & 6 & 14 \\
\hline hhsize1 & 2.355 & 4.778344 & 1.32621 & 3 & 13 \\
\hline Birth Order & 2.355 & 1.512527 & .7105171 & 1 & 6 \\
\hline Biological & 2.355 & .9774947 & .1483515 & 0 & 1 \\
\hline \multicolumn{6}{|c|}{ The dummy variable (1 for biological children, 0 for others) } \\
\hline Asset & 2.355 & .2919089 & .4688285 & 0 & 19.8 \\
\hline Access & 2.355 & 12.969 & 18.71715 & 1 & 600 \\
\hline
\end{tabular}

Source: IFLS4, processed data

Table 2 shows the regression results carried out with the help of STATA14. These results then became the basis for describing the independent variables on the dependent variable in this study. The research results on the impact of working mothers' power on children's human capital in Indonesia can be explained in Table 2. 
Anggaraini \& Setyari

The Impact of Working Mothers' Bargaining Power on Their Children's Human Capital ...

Table 2 Regression results on the impact of working mothers on children's human capital in Indonesia

\begin{tabular}{|c|c|c|c|c|c|}
\hline VARIABLES & (1) & (2) & (3) & $(4)$ & (5) \\
\hline & bols_r & bols_ur & bols_ur1 & bols_ur2 & bols_ur3 \\
\hline \multirow[t]{2}{*}{ rel_educ2014 } & -0.0555 & 0.0184 & $0.0232 *$ & 0.0267 & 0.0208 \\
\hline & $(0.0436)$ & $(0.140)$ & (0.0139) & (0.0237) & (0.0198) \\
\hline \multirow[t]{2}{*}{ rel_inc2014 } & $0.00898 * * *$ & -0.000780 & -0.000807 & $-9.11 e-05$ & -0.00113 \\
\hline & $(0.00161)$ & $(0.000526)$ & $(0.000524)$ & $(0.000946)$ & $(0.000794)$ \\
\hline \multirow[t]{2}{*}{ Location } & & $0.136^{* * *}$ & $0.121^{* * *}$ & $0.142^{* * *}$ & $0.0713^{*}$ \\
\hline & & (0.0288) & $(0.0288)$ & $(0.0502)$ & $(0.0421)$ \\
\hline \multirow[t]{2}{*}{ Access } & & & & & 0.000836 \\
\hline & & & & & (0.00159) \\
\hline \multirow[t]{2}{*}{ BLSM } & & & $-0.105^{* * *}$ & 0.0201 & 0.0152 \\
\hline & & & $(0.0406)$ & (0.0774) & (0.0639) \\
\hline \multirow[t]{2}{*}{ PKH } & & $-0.155^{* *}$ & -0.0175 & 0.0422 & 0.0987 \\
\hline & & $(0.0634)$ & $(0.0660)$ & $(0.129)$ & (0.104) \\
\hline \multirow[t]{2}{*}{ BLT } & & & $-0.200 * * *$ & $-0.220 * * *$ & $-0.133^{* *}$ \\
\hline & & & (0.0399) & $(0.0764)$ & $(0.0641)$ \\
\hline \multirow[t]{2}{*}{ Asset } & & & & $0.0693^{*}$ & $0.0739 *$ \\
\hline & & & & $(0.0376)$ & (0.0379) \\
\hline \multirow[t]{2}{*}{ Women's age } & & $0.00661 *$ & $0.00616^{*}$ & 0.00419 & 0.00483 \\
\hline & & $(0.00346)$ & $(0.00345)$ & $(0.00633)$ & $(0.00534)$ \\
\hline \multirow[t]{2}{*}{ Partner's age } & & -0.00217 & -0.00163 & -0.00709 & -0.00241 \\
\hline & & $(0.00297)$ & $(0.00296)$ & (0.00549) & $(0.00460)$ \\
\hline \multirow[t]{2}{*}{ Children's age } & & $0.922 * * *$ & $0.924 * * *$ & $0.928 * * *$ & $0.945 * * *$ \\
\hline & & (0.00489) & $(0.00488)$ & $(0.00883)$ & (0.00959) \\
\hline \multirow[t]{2}{*}{ HHsize } & & $-0.0581^{* * *}$ & $-0.0521 * * *$ & $-0.0497 * *$ & 0.000327 \\
\hline & & $(0.0107)$ & (0.0107) & $(0.0214)$ & $(0.0195)$ \\
\hline \multirow[t]{2}{*}{ Birth Order } & & $-0.0592 * *$ & $-0.0485^{* *}$ & -0.0183 & $-0.104 * * *$ \\
\hline & & $(0.0238)$ & $(0.0238)$ & $(0.0441)$ & $(0.0361)$ \\
\hline \multirow[t]{2}{*}{ Biological } & & $0.357 * * *$ & $0.371 * * *$ & 0.237 & 0.215 \\
\hline & & $(0.0742)$ & (0.0739) & $(0.149)$ & $(0.134)$ \\
\hline \multirow[t]{2}{*}{ Constant } & $4.543^{* * *}$ & $-5.886 * * *$ & $-5.916 * * *$ & $-5.597 * * *$ & $-6.004 * * *$ \\
\hline & (0.0740) & $(0.117)$ & $(0.116)$ & $(0.221)$ & $(0.193)$ \\
\hline prob. F & 0.000 & 0.000 & 0.000 & 0.000 & 0.000 \\
\hline R-Squared & 0.005 & 0.899 & 0.900 & 0.900 & 0.903 \\
\hline
\end{tabular}

Source: IFLS5 processed with STATA.

Standard errors in parentheses

*** $\mathrm{p}<0.01, * * \mathrm{p}<0.05, * \mathrm{p}<0.1$

The location variable had a significant positive effect on children's human capital in the unrestricted, unrestricted1, unrestricted2, and unrestricted 3 tests. The residence location, namely the demographics of the area in the village or the city, was very different. Generally, children who lived in cities had better quality human capital than those who lived in villages because of advancements in technology and information. Conversely, the access variable, in this case, the distance from residence to school and vice versa from school to residence, did not affect children's human capital. It signified that the farther or closer access from home to school did not influence the child's human capital. Besides, government program assistance had a significant negative effect, showing BLSM with a 
The Impact of Working Mothers' Bargaining Power on Their Children's Human Capital ...

coefficient value of -0.105 in the unrestricted test1, PKH of $-0,155$ in the unrestricted test, and BLT of -0.133 in the unrestricted test3. The negative results indicated that government assistance was still distributed inequality.

Asset ownerships also had a significant positive effect, where the coefficient value showed 0.0693 and 0.0793 on the unrestricted 2 and unrestricted 3 test. It disclosed that the share of assets during the marriage would increase women's bargaining power in decision-making related to children's education. The proportion of power would increase between women and men, depending on their age. From the results obtained, women's age had a significant positive effect with a coefficient value of 0.0061 for unrestricted1. It denoted that women's power increased according to their age. However, the partner's age did not impact the child's human capital, with a coefficient value of -0.0024 . Meanwhile, children's age had a significant positive effect on children's human capital, with a coefficient value of 0.945 for unrestricted3. It indicated that the higher the child's age, the higher the education level taken according to their age.

The coefficient value of the number of family members of -0.0497 had a significant negative effect on children's human capital in the unrestricted 2 test. The negative results indicated that the greater number of family members, the lower the value. It was because the greater the number of family members, the more expenditure in the household. Besides, the birth order variable revealed that the smaller the child had, the greater the opportunity to get a higher education, whereas the child's birth order had a negative effect and a significant result with a coefficient of -0.104 in unrestricted3. It suggested that there was an imbalance between siblings. It could be due to differences in school achievement that was relatively lower than the national standard as the age increased. Moreover, biological children's status had a significant positive effect, with a coefficient value of 0.371 for unrestricted1. It confirmed that biological children status had the opportunity to receive higher education than other children's status.

Based on the regression results obtained, it could be seen that R-square $\left(R^{2}\right)$ was 0.903 or 90.3 percent. It showed that children's human capital in Indonesia was influenced by the impact of women's power to work by 90.6 percent, while 9.4 percent was influenced by other variables not found in the equation or research model used.

The Chow-test was used to test whether there was a significant difference between working mothers' relative education and relative income on the children's human capital in Indonesia.

From Table 3, by testing each of the interest variables in children's human capital, it revealed that the interest variables, namely working women's relative education and relative income, partially did not impact children's human capital in Indonesia. It implied that power could not be reflected only by a few indicators. In other words, each variable could not stand alone, and the partner's power also influenced the household's decisions. 
The Impact of Working Mothers' Bargaining Power on Their Children's Human Capital ...

Table 3 Results of Testing the Effect of Working Mother's Relative Education and Relative Income on Children's Human Capital in Indonesia

\begin{tabular}{|c|c|c|}
\hline & -1 & 2 \\
\hline VARIABLES & bols2 & bols2 \\
\hline \multirow[t]{2}{*}{ Relative_educ } & -0.00575 & \\
\hline & $(0.0156)$ & \\
\hline \multirow[t]{2}{*}{ Relative_income } & & -0.00111 \\
\hline & & $(0.000794)$ \\
\hline \multirow[t]{2}{*}{ Location } & $0.0815^{* *}$ & 0.0679 \\
\hline & $(0.0349)$ & $(0.0419)$ \\
\hline \multirow[t]{2}{*}{ Acess } & 0.000323 & 0.000853 \\
\hline & $(0.000881)$ & (0.00159) \\
\hline \multirow[t]{2}{*}{ Blsm } & 0.0432 & 0.0156 \\
\hline & $(0.0538)$ & $(0.0639)$ \\
\hline \multirow[t]{2}{*}{ PKH } & 0.0201 & 0.101 \\
\hline & $(0.0861)$ & $(0.104)$ \\
\hline \multirow[t]{2}{*}{ BLT } & $-0.184 * * *$ & $-0.131 * *$ \\
\hline & $(0.0534)$ & $(0.0641)$ \\
\hline \multirow[t]{2}{*}{ Asset } & $0.0791 * *$ & $0.0739 *$ \\
\hline & $(0.0367)$ & $(0.0379)$ \\
\hline \multirow[t]{2}{*}{ Women's Age } & 0.000863 & 0.00465 \\
\hline & (0.00444) & (0.00534) \\
\hline \multirow[t]{2}{*}{ Partner's Age } & -0.00269 & -0.00204 \\
\hline & $(0.00385)$ & (0.00458) \\
\hline \multirow[t]{2}{*}{ Children's Age } & $0.943 * * *$ & $0.944 * * *$ \\
\hline & (0.00798) & (0.00959) \\
\hline \multirow[t]{2}{*}{ HHsize } & -0.00463 & 0.000211 \\
\hline & (0.0155) & $(0.0195)$ \\
\hline \multirow[t]{2}{*}{ Birth Order } & $-0.0932 * * *$ & $-0.104 * * *$ \\
\hline & (0.0295) & $(0.0361)$ \\
\hline \multirow[t]{2}{*}{ Biological } & 0.0672 & $0.222^{*}$ \\
\hline & (0.119) & $(0.134)$ \\
\hline \multirow[t]{2}{*}{ Constant } & $-5.681 * * *$ & $-5.989 * * *$ \\
\hline & $(0.169)$ & (0.193) \\
\hline R-squared & 0.900 & 0.902 \\
\hline
\end{tabular}

Source: IFLS5 processed with STATA.

Standard errors in parentheses

$* * * p<0.01, * * p<0.05, * p<0.1$

Table 4 Results of Chow-Test

\section{$F(1,1656)=456.93$}

Prob $>F=0.0000$

Source: IFLS processed with STATA.

The Chow-test results in Table 4 obtained a $F_{\text {test }}$ value of 456,93 and a significance value of 0.0000 , which was smaller than 0.1 or 10 percent alpha, then $\mathrm{HO}$ was rejected. It indicated a significant difference between the effect of working mothers' relative education and relative income on children's human capital in Indonesia. The magnitude of this difference in influence, namely working mother's relative income, had an effect of 
The Impact of Working Mothers' Bargaining Power on Their Children's Human Capital ...

-0.001 . It was higher than the working mother's relative education, which had an effect of -0.005 on children's human capital in Indonesia.

\section{The Effect of Working Mothers' Relative Education on Children's Human Capital in Indonesia}

The projected impact of women's power at work with working mothers' relative education positively and significantly impacted children's human capital in Indonesia. Children's human capital was strongly influenced by the example of a mother in the household. In this case, the entry of women into public employment causes a dual role for women, where domestic work, which was originally a woman's nature, has now developed with emancipation. Education of women in emancipation is now essential, so women should get the education to the highest level. The level of women's education will undoubtedly affect their power in decision-making in the household, such as their children's education. The tendency is that the higher the level of women's education, the more likely it is that decisions taken can be used as a reference in the household.

The higher the relative education of working mothers than their partners, the more the children's human capital will increase. It means that a more educated working mother will provide higher achievement compared to their educated partners. Before, Qian (2008) used educational attainment as an outcome for an analysis of power in China. Besides, Brown (2006) found that more educated parents tended to invest more education in their children. Furthermore, female decision-makers' marginal effect on education investment was greater than that of male decision-makers.

\section{The Effect of Working Mother's Relative Income on Children's Human Capital in Indonesia}

Working mothers' relative income had a positive and significant effect on children's human capital in Indonesia. The income earned by working mothers could give women a direct bargaining position. If women worked to control the money they made, they might have the ability to influence outcomes that required spending directly. Working outside the home and earning an income could provide bargaining power in other forms. A working mother who had relatively more income than their partners would have more power in making household decisions.

Women's employment and income have been positively associated with children's outcomes and their well-being. This study's results are in line with the results of Qian's (2008) study, which revealed an increase in women's income relative to their partner increased girls' survival rate in China. The working mother's income gives them direct bargaining power and control over income as a financial resource to fund decisions, such as school expenses (Doss, 2013). Higher incomes also increase women's bargaining power in negotiations. 
The Impact of Working Mothers' Bargaining Power on Their Children's Human Capital ...

\section{Differences in the Effect of the Impact of Working Mothers on Children's Human Capital in Indonesia}

The working mothers' relative education and relative income had a different effect, where working mothers' income had a greater influence on children's human capital in Indonesia than the working mothers' relative education. It was related to working mothers' ability to directly decide the income allocation they earned themselves compared to their partners' household income. Basically, children's human capital is influenced not only by one party, mother, or father. It means the decision is often collective or decided together. However, the results showed that if a mother worked and earned her own money, she would allocate money directly to increase her child's human capital compared to the money she got from her partner.

This study's results are not in line with several studies, where the power of women who have dual roles as mothers and work is not followed by an increase in women's power in the household. Nurhamida (2013), in her research that aimed to determine power in marriage among working mothers and homemakers, asserted that from the overall data, the power of men who had wives as working mother remained higher so that they had the decision to be involved limitedly in the division of household duties. The power of men in the household remains even though women work. Women who have incomes experience only a slight increase in power and continue to work on the unprofessional division of domestic labor.

Some studies have measured women's power without considering husbands' power, such as Handa's (1996) study using mother's education as a proxy for women's power. The result revealed no significant impact on the highest level of children's education in femaleheaded households in Jamaica. However, considering the significant effects of maternal education in male-headed households, it suggested that women's relative strength could play a role in children's outcomes. Maternal education could show a direct effect of their schooling on children's educational outcomes (Leibowitz, 1974), but did not reflect the indirect effect of their relative ability to negotiate with fathers on resource allocation in household households (Doss, 2013).

\section{Conclusion}

The children's human capital in Indonesia was influenced by the power possessed by working mothers, where the power of working mothers as proxied by the relative education and relative income had a significant effect. The higher the relative education of working mothers than their partners, the more the children's human capital would increase. It denoted that a more educated working mother would provide higher achievement compared to their educated partners. Meanwhile, working mothers' relative income provided direct bargaining power and control over income as a financial resource to fund decisions, such as children's school expenses, so that the higher the relative income of working mothers, the children's human capital would increase with higher educational attainment. 


\author{
Anggaraini \& Setyari \\ The Impact of Working Mothers' Bargaining Power on Their Children's Human Capital ...
}

There was a significant difference between working mothers' projected relative power, relative education, and income to the children's human capital in Indonesia. The relative income of working mothers had a greater influence on children's human capital in Indonesia. It was related to working women's ability to directly decide the income allocation they earned themselves compared to their partners' household income. The children's human capital in Indonesia was influenced not only by the power of working mothers but also by their partners' power.

The test results' implication can be used as a basis for future actions, both in making a policy related to children's human capital, namely in children's education and intrahousehold. This research does not escape from various shortcomings and limitations. This study's limitation is the lack of variables used, where the impact of women's power at work can be measured or proxied by various indicators; however, in this study, women's power to work was proxied only by two indicators: relative education and relative income. Human capital, in this case, children's human capital, only used the children's education indicators. We suggest future research to add more relevant indicators to measure the impact of working mothers' bargaining power and indicators related to human capital.

\title{
References
}

Aji, S., Syarifudin, D., \& Ishak, R. F. (2014). Identifikasi Tipologi Wilayah Perbatasan Antar Kabupaten/ Kota dan Indeks Pembangunan Manusia di Provinsi Jawa Barat. Proceeding Presentasi Hasil Penelitian Hibah Program Desentralisasi, Sentralisasi dan Hibah Internal Unpas. Lembaga Penelitian Universitas Pasundan.

Becker, G. S. (1964). Human capital : a theoretical and empirical analysis, with special reference to education. New York: Columbia University Press.

Becker, G. S. (1975). Investment in Human Capital: A Theoretical Analysis. Journal of Political Economy, 70(5), 9-49. https://doi.org/10.1086/258724

Beegle, K., Frankenberg, E., \& Thomas, D. (2001). Bargaining Power Within Couples and Use of Prenatal and Delivery Care in Indonesia. Studies in Family Planning, 32(2), 130146. https://doi.org/10.1111/i.1728-4465.2001.00130.x

Brooks-Gunn, J., Guo, G., \& Furstenberg, F. F. (1993). Who drops out and who continues beyond high school? A 20-year follow-up of Black urban youth. Journal of Research on Adolescence, 3(3), 271-294. https://doi.org/10.1207/s15327795jira0303 4

Brown, T. A. (2006). Confirmatory factor analysis for applied research. New York: Guilford.

Doss, C. (2013). Intrahousehold Bargaining and Resource Allocation in Developing Countries. The World Bank Research Observer, 28(1), 52-78. Retrieved from http://www.jstor.org/stable/24582372

Doss, C. R. (2006). The Effects of Intrahousehold Property Ownership on Expenditure Patterns in Ghana. Journal of African Economies, 15(1), 149-80. https://doi.org/10.1093/jae/eji025

Ejrnaes, M., \& Pörtner, C. C. (2004). Birth Order and the Intrahousehold Allocation of Time and Education. Review of Economics and Statistics 86(4):1008-1019. https://dx.doi.org/10.2139/ssrn.204569

Felmlee, D. H. (1988). Returning to School and Women's Occupational Attainment. Sociology of Education, 61(1), 29-41. https://doi.org/10.2307/2112307

Friedemann-Sa'nchez, G. (2006). Assembling Flowers and Cultivating Homes: Labor and Gender in Colombia. Lanbam. MD: Lexington Books 


\section{Anggaraini \& Setyari}

The Impact of Working Mothers' Bargaining Power on Their Children's Human Capital ...

Handa, S. (1996). Maternal Education and Child Attainment in Jamaica: Testing the Bargaining Power Hypothesis. Oxford Bulletin of Economics and Statistics, 58(1), 119-137. https://doi.org/10.1111/j.1468-0084.1996.mp58001006.x

Horton, S. (1988). Birth Order and Child Nutritional Status: Evidence from the Philippines. Economic Development and Cultural Change 36(2), 341-354.

Klugman, J., Hanmer, L., Twigg, S., Hasan, T., McCleary-Sills, J., \& Santamaria, J. (2014). Voice and Agency: Empowering Women and Girls for Shared Prosperity. World Bank Publications.

Leadbeater, B. J. (1996). School Outcomes for Minority-Group Adolescent Mothers at 28and 36-Months Post-Partum: A Longitudinal Follow-Up. Journal of Research on Adolescence, 6(4), 629-648. Retrieved from https:// europepmc.org/article/med/12321351

Leibowitz, A. (1974). Home Investments in Children. The Journal of Political Economy, 82(2), 111-135. https://doi.org/10.1086/260295

Mangkuprawira, S., \& Vitalaya, A. (2007). Manajemen Mutu Sumber Daya Manusia. Bogor: Galia Indonesia

Maulana, R. \& Bowo, P. A. (2013). Pengaruh Pertumbuhan Ekonomi, Pendidikan dan Teknologi terhadap IPM Provinsi di Indonesia 2007-2011. Journal of Economics and Policy, 6(2), 163-169. https://doi.org/10.15294/jejak.v6i2.3886

Melliana, A. \& Zain, I. (2013). Analisis Statistika Faktor yang Mempengaruhi Indeks Pembangunan Manusia di Kabupaten/Kota Provinsi Jawa Timur dengan Menggunakan Regresi Panel. Jurnal Sains dan Seni Pomits, 2(2), 237-242. http://dx.doi.org/10.12962/j23373520.v2i2.4844

Nathan, N. (1989). Three Philosophical Research Programmes. Ratio, 2(1), 46-62. https://doi.org/10.1111/j.1467-9329.1989.tb00126.x

Nazara, S., \& Rahayu, S.K. (2014). Program Keluarga Harapan (PKH): Program Bantuan Dana Tunai Bersyarat di Indonesia.

Nurhamida, Y. (2013). Power in Marriage Pada Ibu Bekerja dan Rumah Tangga. Jurnal Psikogenesis, 1(2), 185-198. https://doi.org/10.24854/ips.v1i2.45

Qian, N. (2008). Missing Women and the Price of Tea in China: The Effect of Sex-Specific Earnings on Sex Imbalance. The Quarterly Journal of Economics, 123(3), 1251-85. https://doi.org/10.1162/qjec.2008.123.3.1251

Quisumbing, A.R. \& Maluccio, J.A. (2003), Resources at Marriage and Intrahousehold Allocation: Evidence from Bangladesh, Ethiopia, Indonesia, and South Africa*. Oxford Bulletin of Economics and Statistics, 65, 283-327. https://doi.org/10.1111/1468-0084.t01$1-00052$

Rustiadi, E., Saefulhakim, S., \& Panuju, D. R. (2011). Perencanaan dan Pengembangan Wilayah. Bogor: Crestpent Press \& Yayasan Pustaka Obor Indonesia.

Saskara, I. A. N. (2018). Pernikahan Dini dan Budaya. Jurnal Ekonomi Kuantitatif Terapan, 11(1), 117-125. https://doi.org/10.24843/jekt.2018.v11.i01.p09

Setyari, N. P. W., Widanta, A. A. B. P., \& Purbadharmaja, I. B. P. (2018). Women's Control Over Economic Resources Effect to Family Welfare. JEJAK: Jurnal Ekonomi dan Kebijakan, 11(2), 280-293. https://doi.org/10.15294/jejak.v11i2.16051

Simanjuntak, P. J. (1985). Pengantar Ekonomi Sumber Daya Manusia. Jakarta: Lembaga Penerbit FE-UI.

Sofiani, T. (2009). Membuka Ruang Partisipasi Perempuan Dalam Pembangunan. MUW AZAH: Jurnal Kajian Gender, 1(1), 63-72. Retrieved from http://ejournal.iainpekalongan.ac.id/index.php/Muwazah/article/view/280

Suroto. (1992). Strategi Pembangunan dan Perencanaan Kesempatan Kerja. Yogyakarta: UGM Press. Todaro, M. P., \& Smith, S. C. (2011). Pembangunan Ekonomi. Jakarta: Erlangga. 
United Nation Human Right. (1993). Declaration on the Elimination of Violence against Women. Retrieved from United Nation Human Right. Available at https://www.ohchr.org/EN/ProfessionalInterest/Pages/ViolenceAgainstWomen.asp $\underline{x}$

United Nations Development Programme. (2018). UNDP Transformation Series. Retrieved from United Nations Development Programme. Available at https://www.undp.org/content/undp/en/home/blog.html

Way, N., \& Leadbeater, B. J. (1999). Pathways toward educational achievement among African American and Puerto Rican adolescent mothers: Reexamining the role of social support from families. Development and Psychopathology, 11(2), 349-364. https://doi.org/10.1017/S0954579499002096

Weiss, D. J., Shanteau, J., \& Harries, P. (2006). People who judge people. Journal of Behavioral Decision Making, 19(5), 441-454. https://doi.org/10.1002/bdm.529

Wong, Y. N. (2012). World Development Report 2012: Gender Equality and Development. Forum for Development Studies, 39(3), 435-444. https://doi.org/10.1080/08039410.2012.722769

Wooldridge, J. M. (2016). Introductory Econometrics: A Modern Approach, Sixth Ed. Boston: Cengage Learning. 